\title{
Strategic Supply Chain Partnering in Industrialised Building System
}

\author{
Faridah Muhamad Halil, Mohammed Fadhil Mohammed, \\ Rohana Mahbub, Ani Saifuza Shukur \\ Faculty of Architecture, Planning and Surveying \\ Universiti Teknologi Mara, Shah Alam, Selangor. Malaysia \\ faridahmh@salam.uitm.edu.my
}

\begin{abstract}
The purpose of this paper is to explore the concept of supply chain partnering practiced in Industrialised Building System. The relationship was based on the elements of trust, share a vision, decision-making and continuous improvement. The methodology adopted used quantitative and qualitative approach. Outcomes of the results, the public clients point out on the element of trust in between contractors were based effectiveness of communication. Meanwhile, the private client indicates competence of work as a successful element of trust in supply chain partnering in Industrialised Building System.
\end{abstract}

Keywords: Strategic; Supply Chain; Trust; Mixed Method

eISSN 2398-4279 @ 2018. The Authors. Published for AMER ABRA cE-Bs by e-International Publishing House, Ltd., UK. This is an open access article under the CC BY-NC-ND license (http://creativecommons.org/licenses/bync-nd/4.0/). Peer-review under responsibility of AMER (Association of Malaysian Environment-Behaviour Researchers), ABRA (Association of Behavioural Researchers on Asians) and cE-Bs (Centre for EnvironmentBehaviour Studies), Faculty of Architecture, Planning \& Surveying, Universiti Teknologi MARA, Malaysia.

DOI: https://doi.org/10.21834/ajqol.v3i10.110 


\subsection{Introduction}

Supply chain partnering refers to integration comprised of the network of organizations involved in the different processes and activities that produce the materials, components and services that come together to design, procure and deliver a building. This process involved from the stage at pre- contract until the post contract of the project. During this stage, the selection of a partner to participate in this project is very crucial to the clients. Failure to decide a suitable partner would impact to the project in terms of delay, cost overrun, inequality and no profit gain. Other than that, adversarial relationship practice in supply chain project could impact on the company to success. A study done by Larson (1995) concluded in his research that construction projects that were managed in an adversarial relationship fashion had the lowest of success. Confirmed by Bayramoglu (2000) that adversarial relationships might lead to disputes and delay in projects. Therefore, the need for understanding the concept of supply chain partnering to the clients in Industrialised Building System. The solution to this problem has move towards more collaborative forms of working relationship through supply chain partnering. These modes of relationship previously prevalent in manufacturing and engineering that received the outcomes in projects successfully delivered on time, budget and specification (Baden-Fuller, 1995). In this paper would be highlighted the supply chain partnering that refer to the relationship network with different contractor organizations from upstream relationship in between client and contractor that was selected through the bidding process to participate in projects. However, the selection of prime contractor should consider the downstream link supply chain practiced in the organizations.

\subsection{Literature Review}

\subsection{Elements of Trust in Supply Chain Partnering}

The three essential elements of partnering have been described by Cartlidge,(2009) and are discussed below.

\section{i) Mutual Objectives}

There are mutual objectives to which all parties are fully committed. All parties are open about their own objectives so they can get a better understanding of what each organisation is trying to achieve. Following this, a set of mutual objectives can be drawn up, taking into account the individual organisation's objectives, which can form the basis of the partnering charter.

\section{ii) Decision Making}

Secondly,partnering requires an agreement on how decisions are made, including how any disputes will be resolved. One of the basic elements of partnering is empowerment and the idea that decisions should be made and problems solved at the contractual ways of quickly resolving such matters.

\section{iii) Continuous Improvement}


Finally, the parties must commit to seeking ongoing and measurable improvement in their performance. Key performance Indicator (KPIs) are set by the partnering parties who decide among themselves what should be measured and what targets should be set. The items measured are cost, time and quality.

Based on the above, three (3) essential of elements of partnering which are mutual objectives, decision making and continuous improvement that contribute to the importance of elements in practicing supply chain partnering in industrialised building system. However, the different authors interpreted in the various way contents of an element of partnering in the construction industry. Below showed the keywords or phrases stated by the various authors on the element of partnering in the supply chain in the construction industry as illustrated in Table 1.

Table 1. Element of partnering

\begin{tabular}{|c|c|}
\hline Authors & Elements of Partnering \\
\hline Harnett (1990) & $\begin{array}{ll}\text { - } & \text { Develop co-operative } \\
\text { management team } \\
\text { - } & \text { Common goals } \\
\text { - } & \text { Act in good faith }\end{array}$ \\
\hline Cook \& Hancher (1990) & $\begin{array}{ll}\text { - } & \text { Commitment } \\
\text { - } & \text { Trust } \\
\text { - } & \text { Mutual advantage \& } \\
& \text { opportunity } \\
\end{array}$ \\
\hline Cll ( 1991) & $\begin{array}{ll}\text { - } & \text { Long term commitment } \\
\text { - } & \text { Trust } \\
\text { - } & \text { Shared Vision }\end{array}$ \\
\hline $\begin{array}{l}\text { Mosley, Moore, Slale, \& Burns } \\
\text { (1991) }\end{array}$ & $\begin{array}{ll} & \text { Equity } \\
\text { - } & \text { Investment } \\
\text { - } & \text { Shared risk } \\
\text { - } & \text { Rewards }\end{array}$ \\
\hline Cowan, Gray, \& Larson (1992) & $\begin{array}{ll}\text { - } & \text { Problem resolution } \\
\text { - } & \text { Mutual goals } \\
\text { - } & \text { Shared risk } \\
\text { - } & \text { Commitment from top } \\
& \text { management } \\
\end{array}$ \\
\hline Weston \& Gibson (1993) & $\begin{array}{ll}\text { - } & \text { Win -win } \\
\text { - } & \text { Joint problem - solving } \\
\text { - } & \text { Joint project team } \\
\text { - } & \text { Risk sharing } \\
\text { - } & \text { Mutual goal } \\
\end{array}$ \\
\hline
\end{tabular}




\begin{tabular}{|c|c|}
\hline Authors & Elements of Partnering \\
\hline Jones \& Kaluarachchi (2007) & $\begin{array}{ll}\text { - } & \text { Trust } \\
\text { - } & \text { Shared vision } \\
\text { - } & \text { Long term commitment }\end{array}$ \\
\hline Wilson (1995) & $\begin{array}{ll}\text { - } & \text { Commitment } \\
\text { - } & \text { Mutual objectives } \\
\text { - } & \text { Trust and integrity } \\
\end{array}$ \\
\hline Larson (1995) & $\begin{array}{ll}\text { - } & \text { Team building } \\
\text { - } & \text { Conflict management } \\
\text { - } & \text { Mutual goals }\end{array}$ \\
\hline Pheng, (1999) & $\begin{array}{ll}\text { - } & \text { Trust } \\
\text { - } & \text { Commitment } \\
\text { - } & \text { Share vision } \\
\end{array}$ \\
\hline
\end{tabular}

From the distribution of the elements of partnering in supply chain above concealed by the various authors is seen that the elements of partnering is crucial to practice in between supply chain involved in industrialised projects. Summarised from the above, Table 2. show the most common elements of partnering in supply chain as follows;

Table 2. Most common element of partnering

\begin{tabular}{|l|l|}
\hline Most common element of partnering & No. of Authors \\
\hline Trust & 7 \\
\hline Goal and objectives / shared vision & 7 \\
\hline Commitment & 6 \\
\hline Shared risk & 3 \\
\hline Teamwork/collaboration & 5 \\
\hline Win-win & 1 \\
\hline Problem resolution & 3 \\
\hline Openness & 1 \\
\hline Mutual respect & 1 \\
\hline Rewards & 1 \\
\hline
\end{tabular}

The most common elements in partnering, stated by seven authors was trust and goal and objectives or shared vision (cook \& Hancher, 1990; Cll,1991;Weston \& Gibson, 1993; Jones, 1994; Wilson,1995; Larson, 1995 and Pheng, 1999) and goal and objectives or shared vision (Harnett,1990;Moore et al,1992; Cowan et al,1992; Weston \& Gibson,1993; Jones,1994; Wilson,1995 and Pheng, 1999). Trust and shared vision show the most frequently mentioned by the researchers as importance element to established during the supply chain partnering in projects. Trust in industrialised building project can be developed if partners are satisfied with the first project given. Based on a project's good reputation, the next project would be given to the partners according to the successor of the previous project. 
Agreed by Lazar (2000) that clients and contractors understand what trust is and how trust develops. They understand the roles that trust plays in establishing a successful supply chain partnering relationship.

\subsection{Experience from Successful Countries}

Lesson learnt from the other countries how they practiced supply chain partnering is discussed below.

\section{Swedish Industrialised Housing}

Hook \& Stehn (2008) disclose that industrialised housing production in the Swedish development sector involved different levels that are on-site and off-site activities. Three (3) types can be distinguished:

a. Off-site prefabrication of materials and parts

b. Pre-fabrication of components and sub -assemblies

c. Pre-fabrication to where work is completed off-site in a factory environment.

Fig.1. illustrates how the construction process using industrialised building system is practiced in Swedish construction from design to factory production. The standardisation of components in the building system resulted in a number of Swedish companies using industrialised timber volume element (TVE) housing production, where about $80 \%$ of the work was completed off-site. The TVE is a closed three-dimensional structure built up with components and sub-assemblies of floor, roof, wall elements and finished with the electrical installation, flooring, cabinets, wardrobes and finishing. The volumes are then transported to the construction site and assembled by the organisation's personnel into a complete structure. Findings from the case study, in industrialised building system there was a necessity for clear top management strategies in order to practice the modern method of construction. An explicit top-down and bottom-up approach is diffused to workers.

A working culture in the IBS will be achieved when people find strategies, practices and tools to work with components. Holmen, Pedersen, \& Torvatn (2004) revealed that an organisation's innovation is assumed to be a function of the extent to which they engage in relationships comprising technological cooperation and development. The understanding of the need for a close relationship and networks in the construction industry enables organisations to be innovative and to develop new technologies, products and processes.

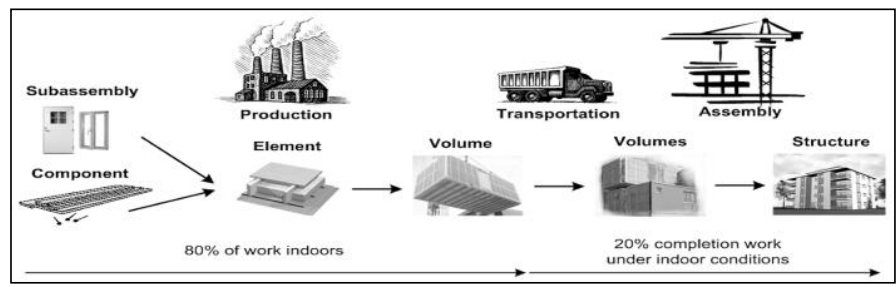

Figure 1: Industrialised TVE Housing Production (Sources: from Hook \& Stehn, 2008) 


\subsection{Methodology}

The research methodology adopted in this study used a quantitative and qualitative method called the mixed method. The benefits of using this method are that it presents an opportunity to seek verification in the results from different methods, and can find similar or different patterns. By using both quantitative and qualitative measures, one can expand the breadth and depth of a study to examine various aspects. This method is particularly helpful as certain components of research are better addressed using more than one method (deMarrais \& Lapan, 2004). In this research, the sample of studies was based on the population for the private client and purposive sampling for the public client. The private clients were all developers registered with REHDA Directory. This sampling is a cross-sectional study in between public and private clients. Both sampling can provide a different opinion and opportunity to seek verification of the result received based on the similar questions asked to the difference respondents.

\subsection{Findings and Discussions}

The results of the studies are as follows;

\subsection{Quantitative Result}

Table 3 shows trust attributes between clients and contractors. Public clients agreed that the development of trust between contractors was based on the elements of frequency and effectiveness of communication at a mean value of 4.29. Private clients agreed on competence of work at a mean value of 4.17 . Based on this result, trust can be developed if partners are satisfied with the pre-agreed contract terms with fair risk allocation and benefits sharing. However, continuous improvement of communication and the efficiency of information flow, working competence and speed of problem solving of partners are also essential to enhance the partner's trust during the project period. The elements of trust risk, integrity, intentions, openness, ability and past experience contribute to the success of collaboration among partners (Cartlidge, 2009).

Table 3: Trust Attributes in Public and Private Clients

\begin{tabular}{|c|c|c|c|c|c|c|c|c|}
\hline \multirow[b]{2}{*}{$\begin{array}{l}\text { Trust } \\
\text { attributes }\end{array}$} & \multicolumn{4}{|c|}{ Public client } & \multicolumn{4}{|c|}{ Private client } \\
\hline & Mean & Mode & $\begin{array}{l}\text { Std } \\
\text { dev }\end{array}$ & Rank & Mean & Mode & $\begin{array}{l}\text { Std } \\
\text { dev }\end{array}$ & Rank \\
\hline $\begin{array}{l}\text { Competenc } \\
\text { e of work }\end{array}$ & 4.21 & 4 & 0.509 & 2 & 4.17 & 4 & 0.510 & 1 \\
\hline $\begin{array}{l}\text { Problem } \\
\text { solving }\end{array}$ & 4.21 & 4 & 0.588 & 3 & 4.10 & 4 & 0.510 & 3 \\
\hline $\begin{array}{l}\text { Frequency } \\
\text { and } \\
\text { effectivene } \\
\text { ss of } \\
\text { communica } \\
\text { tion }\end{array}$ & 4.29 & 4 & 0.550 & 1 & 4.03 & 4 & 0.501 & 5 \\
\hline
\end{tabular}


Muhamad Halil, F., et.al, / Asian Journal of Quality of Life (AjQoL), 3(10)) Mar / Apr 2018 (p.139-148)

\begin{tabular}{|l|l|l|l|l|l|l|l|l|}
\hline $\begin{array}{l}\text { Trust } \\
\text { attributes }\end{array}$ & Mean & Mode & $\begin{array}{l}\text { Std } \\
\text { dev }\end{array}$ & Rank & Mean & Mode & $\begin{array}{l}\text { Std } \\
\text { dev }\end{array}$ & Rank \\
\cline { 2 - 9 } $\begin{array}{l}\text { Alignment } \\
\text { of effort } \\
\text { and } \\
\text { rewards }\end{array}$ & 3.33 & 3 & 0.702 & 12 & 3.58 & 4 & 0.615 & 10 \\
\hline $\begin{array}{l}\text { Effective } \\
\text { and } \\
\text { sufficient } \\
\text { information } \\
\text { flow }\end{array}$ & 4.13 & 4 & 0.741 & 4 & 3.92 & 4 & 0.587 & 7 \\
\hline $\begin{array}{l}\text { Sense of } \\
\text { unity }\end{array}$ & 3.58 & 4 & 0.654 & 10 & 3.69 & 4 & 0.673 & 9 \\
\hline $\begin{array}{l}\text { Respect } \\
\text { for, and } \\
\text { appreciatio } \\
\text { of, the } \\
\text { system }\end{array}$ & 3.83 & 4 & 0.637 & 7 & 3.73 & 4 & 0.627 & 8 \\
\hline $\begin{array}{l}\text { Share } \\
\text { similar } \\
\text { cultures } \\
\text { and values }\end{array}$ & 3.57 & 3 & 0.728 & 11 & 3.53 & 4 & 0.725 & 12 \\
\hline $\begin{array}{l}\text { Long-term } \\
\text { relationship }\end{array}$ & 3.71 & 4 & 0.751 & 8 & 3.99 & 4 & 0.627 & 6 \\
\hline $\begin{array}{l}\text { Financial } \\
\text { stability }\end{array}$ & 4.13 & 4 & 0.741 & 5 & 4.12 & 4 & 0.672 & 2 \\
\hline Reputation & 3.96 & 4 & 0.806 & 6 & 4.09 & 4 & 0.574 & 4 \\
\hline $\begin{array}{l}\text { Adoption } \\
\text { dispute } \\
\text { resolution } \\
\text { techniques }\end{array}$ & 3.62 & 4 & 0.576 & 9 & 3.56 & 4 & 0.672 & 11 \\
\hline $\begin{array}{l}\text { All } \\
\text { elements }\end{array}$ & 3.88 & 3.92 & 0.420 & - & 3.88 & 4 & 0.354 & - \\
\hline
\end{tabular}

\subsection{Qualitative Result}

A semi-structured interview was conducted to gather in-depth information from the public and private clients on the strategic partnering practice in the IBS. A set of questions was prepared that was interrelated with the questionnaire survey. Taylor, Sinha, \& Ghoshal (2006) stated that a structured interview uses an interview schedule with a set of predetermined questions in a set sequence. An interview schedule is a formal list used in interviews to aid in the systematic collection of data through questions. The ten (10) respondents from public and ten (10) respondents from private clients were interviewed. The unit of analysis was based on the organisations and the expert's from the top management was selected.

Table 4: Elements of trust successful supply chain partnering in IBS

\begin{tabular}{|l|l|l|l|}
\hline Question & Theme & $\begin{array}{l}\text { Frequency of } \\
\text { Responses }\end{array}$ & Percentage (\%) \\
\hline $\begin{array}{l}\text { Elements of trust } \\
\text { for successful }\end{array}$ & Public Clients \\
\hline
\end{tabular}




\begin{tabular}{|c|c|c|c|c|}
\hline supply chain & a) & Problem solving & 3 & 15 \\
\hline partnering in IBS? & $\begin{array}{l}\text { b) } \\
\text { c) } \\
\text { d) }\end{array}$ & $\begin{array}{l}\text { Good performance (financial, } \\
\text { quality of work and on time } \\
\text { completion) } \\
\text { Good Communication } \\
\text { Reasonable cost }\end{array}$ & $\begin{array}{l}8 \\
4\end{array}$ & $\begin{array}{l}40 \\
20\end{array}$ \\
\hline & TOT & & 20 & 100 \\
\hline & Priv & Clients & & \\
\hline & $\begin{array}{l}\text { a) } \\
\text { b) }\end{array}$ & $\begin{array}{l}\text { Trust } \\
\text { Good performance (financial, } \\
\text { quality of work and on time } \\
\text { completion) }\end{array}$ & $\begin{array}{l}4 \\
17\end{array}$ & $\begin{array}{l}15 \\
65\end{array}$ \\
\hline & c) & Good Communication & 2 & 8 \\
\hline & d) & Reasonable cost & 3 & 12 \\
\hline & TOT & & 26 & 100 \\
\hline
\end{tabular}

Table 4 indicates that information received from the public and private clients on the variable that contributes to the successful supply chain partnering involved in between clients and contractors. A public client indicates that element of problem solving at $15 \%$, follow by good performance at $25 \%$, good communication at $40 \%$ and reasonable cost at $20 \%$. However, private clients indicate $65 \%$ for good performance, trust at $15 \%$, a reasonable cost at $12 \%$ and good communication at $8 \%$. Public clients believe that element of good communication as a main factor that contributes to the successful supply chain partnering. Confirmed with a result from the quantitative showed that the public clients point out on the element of frequency and effectiveness of communication as a primary element of successful in supply chain partnering. Explained by Wong \& Cheung (2004) in his paper revealed that trust can be developed if partners are satisfied with the pre-agreed contract terms regarding fair risk allocation and benefits sharing. However, the continuous improvement of communication and the efficiency of information flows, as well as the working competence and the speed of problem -solving. Meanwhile, the private clients indicate that good performance as a crucial element for supply chain partnering in industrialised building system.

\subsection{Conclusion}

The conclusion from the study, public clients point out on the element of trust in between contractors' ware based on the frequency and effectiveness of communication and private client indicates competence of work as a successful element of trust in supply chain partnering in Industrialised Building System. Supply chain partnering in industrialised building system should be practiced by both public and private sector to ensure successful completion of the project on time, cost and quality. The selection of suitable contractor in projects should be clear by the clients. Not all contractors should be appointed in this type of construction. A special calling for tender for contractors that have a capabilities in terms of knowledge in method construction in industrialised building system, good involvement in supply chain 
management, financially strong and innovative approach should be practiced. Government policy should be clear on the encouragement of contractors to involve in industrialised building system project. In industrialised system, only contractors with good capabilities in terms of financial, technology and management skills area suitable to involve in this method of construction. The tendering procedure that open to all contractor need to review. The tender should be open to IBS contractors that have skills, knowledge, financially strong and good management need to be exercised. The study shows that the benefits of trust received demonstrate a successful project completion, best value for money through sustainable business, reduce cost and improved overall quality of the project and innovative.

\section{Acknowledgement}

The authors would like to extend the utmost appreciation to all participated agencies especially staffs public and private Department, Malaysia and utmost respondents for their exceptional dedication and enthusiasm and for sharing their valuable time and support.

\section{References}

(CII), Construction Industry Institute. (1991). In search of partnering excellence. (Special Publication No. 17-1). Retrieved 30/3/2010, from Report by the Partnering task Force of CII, Austin, Texas

Baden-Fuller, C. (1995). Strategic Innovation, Corporate Entrepreneurship and Matching out-side-in to Inside-out Approach to Strategy to Strategy Research British Journal of Management, 6(3), 3-17.

Bayramoglu, S. (2000). Partnering : Applicability in the Turkish Construction Sector. Istanbul Technical University.

Cartlidge, Duncan (Ed.). (2009). New Aspects of Quantity Surveying Practice. United Kingdom: ButterworthHeinemann.

CIDB. (2006). Industrialized Building System in Malaysia. In I. E. Ismail, I. N. Bahri, R. Ahmad \& S. N. Aziz (Eds.), (pp. 3-19). Kuala Lumpur.

Che Bond Ahmad, Izzarul Hafni Mohd Hashim, Jamalunlaili Abdullah and Jasmee Jaafar. (2012). Stakeholders' Perception on Buffer Zone Potential Implementation: A Preliminary Study of Tasek Bera, Malaysia. Social Behavioral Science, 50, 582-590.

Cook, E. L., \& Hancher, D. E. (1990). Partnering : Contracting For The Future. Journal of Management in Engineering, 6 (4), 431-446.

Cowan, C., Gray, C., \& Larson, E. (1992). Project Partnering. Project Management Journal, XXII, 5-11.

DeMarrais, Kathleen, \& Lapan, Stephen D. (Eds.). (2004). Foundations for ResearchMethods of Inquiry in Education and the Social Science. London: Lawrence Erlbaum Associates.

Gidado, K. I. (1996). Project Complexity: the Focal Point of Construction Production Planning. Construction Management and Economics, 14, 213-225. 
Holmen, Elsebeth, Pedersen, Ann Charlott, \& Torvatn, Tim. (2004). Building relationship for technological innovation. Journal of Business Research, 58, 1240-1250.

Hook, Matilda, \& Stehn, Lars. (2008). Lean principles in industrialized housing production:the need for a cultural change. Lean Construction Journal, 20-33.

Jones, Keith, \& Kaluarachchi, Yamuna. (2007). Operational Factors Affecting Strategic Partnering in UK Social Housing. Engineering, Construction and Architectural Management, 14 (4), 334-345.

Larson, E. (1995). Project Partnering : Results of Study of 280 Construction Projects. Journal of Management in Engineering, 10 (2), 30-35.

Lazar, F. (2000). Project Partnering: Improving the likelihood of win-win Outcomes. Journal of Management in Engineering, 16(2), 71-83.

Mosley, D., Moore, C., Slale, M., \& Burns, D. (1991). Partnering in the Construction Industry: Win-Win Strategic Management in Action. National Productivity Review, Summer, 319-325.

Pheng, Low Sui. (1999). The Extension of Construction Partnering for Relationship Marketing. Marketing Intelligence and Planning, 17(3), 155-160.

Rahman, M. Motiar, Asce, M., \& Kumaraswamy, Moham M. (2004). Contracting Relationship Trends and Transitions. Jounal of Management in Engineering.

Taylor, Bill, sinha, Gautam, \& Ghoshal, Taposh (Eds.). (2006). Research Methodology

A Guide for Researchers in Managemnet and Social Sciences. New Delhi: Prentice Hall of India Private Limited.

Wong, P. S. P., \& Cheung, S. (2004). Trust in Construction Partnering : Views from Parties of the Partnering Dance. International Journal of project Management, 22, 437-446. 